\title{
MEMORY, TRAUMA, PERFORMANCE
}

\author{
Diana Taylor* \\ New York University
}

\begin{abstract}
A B STRACT
Trauma is a way of transmitting the past in the now, which gets re-activated full force. This paper discusses the durational nature of trauma, of history as lived, and as embodied practice.
\end{abstract}

\section{KEYWORDS}

Performance, trauma, memory

2006: Pedro Matta, a tall, strong man walked up to me when I arrived at Villa Grimaldi, a former detention and torture camp on the outskirts of Santiago de Chile. $\mathrm{He}$ is a survivor who twice a month or so gives a guided visit to people who want to know about the site. He greets me in English and hands me a book he has written: "A Walk Through a $20^{\text {th }}$ Century Torture Center: Villa Grimaldi, A Visitor's Guide." I tell him that I am from Mexico and speak Spanish. "Ah," he says, his eyes narrow as he scans me, "Taylor, I just assumed..."

Matta tells me about his arrest in 1975 for being a student activist, his time as a political prisoner in Villa Grimaldi, his exile to the U.S. in 1976 and his work as a private detective in San Francisco until he returned to Chile in 1991. State violence, as in the rest of the Southern Cone, was about breaking the social body that opposed neoliberal economic policy. He used his investigative skills to identify the prisoners who passed through the camp, and name the torturers stationed there.

The site is expansive. It looks like a ruin or a construction site, there is some old rubble and signs of new building - a transitional space, part past, part future. A sign at the entrance, Parque Por la Paz Villa Grimaldi, informs visitors that 4500 people were tortured here and 226 people were disappeared and killed between 1973 and 1979. This place is simultaneously a torture camp, a memory site, and a peace park. The sign reminds us that this tragic history belongs to all of us, and asks us to behave respectfully so that it might remain and continue to instruct. Lesson One, clearly, is that this place is "our" responsibility in more ways than one.

Matta, a formal man roughly my age, walks me over to the small model of the torture camp to help visualize the architectural arrangement of a place now gone: Cuartel Terranova (barrack "new land"). The mock-up is laid out, like a coffin, under a large

*diana.taylor@nyu.edu 
plastic sunshade. The model reminds me that the death space is (fortunately) one that I cannot see and never know except through all manner of mediation. Even though I am there, I will not experience it "in person." So what is the purpose of the visit? Does the space itself convey the event? Or the fact that I am here in person with Matta, who takes me on the recorrido (or "walk through"). As he speaks, his voice is strained and he clears his throat often.

The compound, originally a beautiful nineteenth century villa, was taken over by DINA, Augusto Pinochet's Special Forces to interrogate the people detained by the military during the massive round-ups. ${ }^{1}$ In the late 1980 s, one of the generals sold it to a construction company owned by the Pinochet family to tear down and replace with a housing project. Survivors and human rights activists could not stop the demolition but after much public outcry and heated contestation, they did secure the space as a memory site and peace park in $1995 .^{2}$ Three epochs, with three histories, overlap on this space that even now has multiple functions: evidentiary, commemorative, reconciliatory, and pedagogical.

The miniature camp positions us as spectators. We stand above the model, looking down on its organizational structure. I am permitted to identify without identifying. The mock-up or "fake" gives others at least a glimpse of the "truth" of Terranova. The metal gate that served as the main entrance to our top left allowed passage for vehicles that delivered the hooded captives up to the main building. Matta's language and our imaginations populate the inert space. He points to the tiny copy of the large main building that served as the center of operations for DINA - here the military planned who they would target and how and they evaluated the results of the torture sessions. A short-wave radio station kept the military personnel in contact with their counterpoints throughout South America. The small buildings that run along the perimeter to the left mark where the prisoners were divided up, separated, and blindfolded - men there, women there. Miniature drawings made by survivors line the periphery - hooded prisoners pushed by guards with rifles for their thirty seconds at the latrines; a hall of small locked cells guarded by an armed man; a close-up drawing of the inside of one of the cells in which a half dozen shackled and hooded men are squeezed in tightly; an empty torture chamber with a bare metal bunk bed equipped with leather straps, a chair with straps for arms and feet, a table with instruments.

Matta points to other structures on the model. It is clear that the model gives him a sense of control - he no longer needs to fully relive the image to describe it - he can externalize and point to it. He is explicit about the criminal politics and very clear in his condemnation of the C.I.A.'s role in the Chilean crisis. His eyes challenge me, and then he remembers I am not that audience - an audience but not that audience.

\footnotetext{
${ }^{1}$ DINA stands for Dirección Nacional de Inteligencia (National Intelligence Directorate).

${ }^{2}$ MEADE. Holding the junta accountable: Chile's "sitios de memoria" and the history of torture, disappearance, and death" writes that Villa Grimaldi was the "only "memorial" of torture in Latin America when it was built in 1995. Now "Parque de la Memoria" and ESMA in Buenos Aires also function as memorials.
} 
Looking down at the model, I see we are standing on the site of the main building, usurping the military's place. Looking offers me the strange fantasy of seeing or grasping the "whole," the fiction that I can understand systemic criminal violence even as we position ourselves simultaneously in and above the fray. We are permitted to identify without identifying. This happened there, back then, to them, by them.... The mockup or "fake" gives others at least a glimpse of the "truth" of Terranova and I wonder how memory sites and mock-ups make criminal violence visible? The "other" violence, the economic policies that justified and enabled the breaking of bodies, remains safely outside the frame.

I look up and around at the 'place itself - emptied though not empty - empty of something palpable in its absence. The remains of a few original structures and replicas of isolation cells and a tower dot the compound. Matta speaks in the third person, about the role of torture in Chile - one half million people tortured and 5000 killed out of population of 8 million. One in 16 . He speaks about the development of torture as a tool of the state from its early experimental phase to the highly precise and tested practice it became. Pinochet chose to break rather than eliminate his "enemies" - the population of ghosts, or individuals destroyed by torture, thrown back into society would be a warning for others. Matta's tone is controlled and reserved. He is giving information, not personal testimony, as he outlines the daily workings of the camp, the transformation of language as words were outlawed. "Crimenes," "desaparecidos," and "dictadura" (crimes, disappeared, and dictatorship) were replaced by "excesos," "presuntos," and "gobierno military" (excesses, presumed, military government).

As we walk, he describes what happened where and I notice that he keeps his eyes on the ground, a habit born of peering down from under the blindfold he was forced to wear. Matta walks us towards the original entryway - the massive iron-gate now permanently sealed as if to shut out the possibility of further violence. From this vantage point, it is clear that another layer has been added to the space. A wash of decorative tiles, chips of the original ceramic found at the site, form a huge arrow-like shape on the ground pointing away from the gate towards the new "peace fountain" ("symbol of life and hope" according to Matta's booklet and a large performance pavilion. The architecture participates in the rehabilitation of the site. The cross-shaped lay-out moves us from criminal past to redemptive future. Matta ignores that for the momenthe is not in the peace park. This is not the time for reconciliation. His traumatic story, like his past, weighs down all possibility of future. He continues his recorrido through the torture camp. ${ }^{3}$

The shift in Matta is gradual - he begins to reenact ever so subtly as he re-tells. Looking down, I see the colored shards of ceramic tiles and stones that now mark the places where buildings once stood and the paths where victims were pushed to the latrine or torture chambers. As I follow, I too know my way by listening and keeping my eyes on the ground: "Sala de tortura." "Celdas para mujeres detenidas."

I follow his voice. Gradually, his pronouns change - they tortured them becomes they tortured $u s$. He brings me in closer. His performance animates the space and keeps

${ }^{3}$ LAZZARA'S. Chile in transition: the poetics and politics of memory. 
it alive. His body connects me to what Pinochet wanted to disappear, not just the place but the crimes. Matta's presence performs the claim, embodies it, le da cuerpo. He has survived to tell. Being in place with him communicates a very different sense of the events than looking down on the model - it brings the past up close, past as actually not past. Now. Here. And in many parts of the world, as we speak. I am suddenly rooted to place restored as practice. I too am part of this scenario now; I have accompanied him here. My eyes look straight down, mimetically rather than reflectively, through his downturned eyes. I do not see really; I imagine. I presenciar; I presence (as active verb). Embodied cognition, neuroscientists call this, but we in performance studies have always understood it as mimesis and empathy - we learn and absorb through contact with other people. I participate not in the events but in the transmission of his affective relationship to place by listening to his voice and following his steps. My presencing offers me no sense of control, no fiction of understanding. He walks, he tells, he points. The isolation cells, he says, were one meter by one meter - five men where squeezed, upright, into that space. There is an original small brick semi-circle there where the captives were allowed to sit each day for a few minutes. He sits. Remembers. He says nothing. When he gets to the memorial wall marked with the names of the dead (built twenty years after the violent events) he breaks down and cries. He cries for those who died but also for those that survived. "Torture," he says, "destroys the human being. And I am no exception. I was destroyed through torture." This is the climax of the tour. The past and the present come together in this admission. Torture works into the future; it forecloses the very possibility of future. The torture site is transitional but torture itself is transformative - it turns societies into terrifying places and people into zombies. ${ }^{4}$

When Matta leaves the memorial wall his tone shifts again. Now he is more personal and informal in his interaction with me. We talk about how other survivors have dealt with trauma, about similarities and differences with other torture centers and concentration camps. He says he needs to come back. The walk through reconnects him with his friends who were disappeared. Whenever he visits with a group who is interested in the subject, he feels he is doing what he wishes one of his friends had done for him had he been the one disappeared. Afterwards he goes home physically and emotionally drained, he says, and drinks a liter of fruit juice and goes to sleep - he doesn't get up until the following morning. We continue to walk, past the replica of the water tower where the high value prisoners were isolated, past the "sala de la memoria" (memory room) - one of the few remaining original buildings that served as the photo and silkscreen rooms. At the pool, also original, he tells one of the most chilling accounts told to him by a collaborator. At the memory tree, he touches the names of the dead that hang from the branches, like leaves. Different commemorative art pieces remind us that "El olvido esta lleno de memoria" (forgetting is full of memory. And of course, the ever hopeful Nunca Más. He barely notices the fountain - the Christian overlay of redemption was the government's idea, clearly.

${ }^{4}$ GODOY-ANATIVIA. The body as sanctuary space: towards a somatic topography of torture. 
Later I learn Matta does the visit the same way every time - stands in the same spot, recounts the same events, cries at the Memorial Wall. Is Matta a professional trauma survivor? Is trauma, like performance, known by the nature of its repeats: "never for the first time"? We speak of trauma only when the event cannot be processed and produces the characteristic aftershocks. Trauma, like performance, is always experienced in the present. Here. Now.

But it's also more complicated than that. As for the Mothers of Plaza de Mayo, I believe, the ritualized tour offers him both personal consolation and revenge. Memory is a tool and a political project - an honoring of those who are gone, and a reminder to those who will listen that the victimizers have gotten away with murder. His tour, like the Mother's march, bears witness to what gets spectacularized-a society in which judicial systems cannot bring perpetrators to justice - and what gets invisibalized rapacious economic systems that disappear certain populations. Yet the walk-through, like the march, also makes visible the memory paths that maintain another topography of place and practice, not of terror but of resistance - the will not only to live but also to keep memory alive.

I can understand what Matta is doing here better than I can understand what I am doing here. Am I his witness? His audience? A voyeur of trauma tourism? What does Matta's performance want of me as audience or as witness? What does it mean about witnessing and the quality of being in place? To witness, a transitive verb, defines both the act and the person carrying it out; the verb precedes the noun - it is through the act of witnessing that we become a witness. Identity relies on action. We are both the subject and the product of our acts. Matta is the witness for those who are no longer alive to tell; he is the witness to himself as he tells of his own ordeal; he is a witness in the juridical sense - having brought charges against the Pinochet dictatorship. He is also the object of my witnessing - he needs me to acknowledge what he and others went through in Villa Grimaldi. The transitivity of "witness" ties us together - that is one reason he is keen to gauge the nature of his audience.

Torture, of course, produces the opposite of witnessing - it breaks personal and social bonds and guts all sense of community and responsibility. Torture isolates and paralyzes both victims and by-standers, who are tempted to look away. Percepticide I have called this elsewhere. This is why governments continue to practice torture even though they know that they receive no "actionable" information. It is inaction they seek- anything from a passive population to Pinochet's community of ghosts. Walking through Villa Grimaldi with Matta, the over-size issues of human rights violations and crimes against humanity - too large and general on one level - take on an immediate and embodied form. This is the strength and weakness of this kind of memorialization it is so personalized and concentrated that it tends to focus just on the designated victims and space. We all live in proximity to criminal violence - and though some have felt it more personally than others, this violence is never just personal. If we focus only on the individual and the trauma we risk evacuating the politics. Standing there, together, bringing the buildings and routines back to life, we bear witness not just to the personal loss, but to a system of power relations, hierarchies, and values that not only allowed but required the destruction of others. 
My job, as I understand it following Matta deeper down the paths, is to keep those memory paths fresh and do something - acknowledge the violence generated by our governments and our economic policies, or write about the place, or donate money, or bring other people. As the multi-tiered space itself invites, I recognize the layers and layers of political and corporeal practices that have created these places, the histories we bring to them, and the emotions that get triggered as we walk through them in our own ways.

2010: I heard that the renovations on Villa Grimaldi had been completed under the Michelle Bachelet government (herself a victim of detention and torture in Villa Grimaldi), and outfitted with an educational and resource center. An audio tour was available in several languages. Clearly, it was time to go back - this time without a survivor to try to understand how presence and voice affected my understanding of the space. Again, I chose the "tour" in Spanish. The quiet, rhythmic voice of the unidentified female "guide" - I found out later - belonged to a well-known actress of Chilean telenovelas (or soap operas). But without knowing that, I sensed that the young, fresh voice had been untouched by the violence she was describing. The instructions are clear from the outset - I am to move to the different points in the audio tour, marked on the Xeroxed map and, at the site, by the same tile markers. But this was a radically different experience. The homemade sign at the gate, reminding me to behave, is gonereplaced by a steel plinth, a sign of its incorporation into an institutional system. I feel alone and confused as I start the walk-through. I fumble with the buttons on the digital recorder and feel silly with the headphones even though there is almost no one else there. I get impatient as the voice tells me in a matter of fact way the political acts that lead to the creation of this torture center. I feel tempted to pull the headphones off, but resist temptation. When the audio segment ends, I stop, fumble on the map for the next "stop" and move towards it.

The voice without the body radically changes my experience of being in place. Alone, I do not respond and (perhaps related) I feel less responsible. There is no "I" or "me" envisioned in this audio tour - no human being who challenges me or holds me in part responsible for what happened. The communicative pact is between two unknowns, whose reasons for participating in this project remain unexplored. Instead of bring the past up close, and making evident the networks that link us not just affectively but politically, the audio shuts (and locks) the gateway to that past. From a safe now, I enter into the land of long ago and far away.

The "recorrido" follows the same route taken by Matta - the model camp the locked iron-gate, the cells and memory wall. But there are some new buildings, (locked) and the excavation dug up remnants of the original villa. Now the site is much more ordered, the paths are clearly marked and illuminated - some of the beauty of the villa restored with the wading pools and multiple fountains. The forbidding walls to the exterior have been knocked down and the site has been integrated, visually and politically, to the surrounding neighborhood. The neighboring houses are clearly visible. Their view of the "park" must be quite pleasant. The torture site has been domesticated-the visceral pain I felt with Matta has given place to repose. This clearly transmits the sense of a different political moment. With the opening of the new Museum of Memory 
and Human Rights this year, it appears that the contestation has given way to a time of acceptance and memorialization.

I keep walking. The crisp soft voice of the audio that draws on a great number of testimonies gives far more detail than Matta did. There are more dates, figures, facts. The separation of data into short bits makes sense in one way, of course - supposing that the listener will have time to move from place to place. But the segments are disturbing, not just in their content but in their fragmentation. They start and end abruptly - often after a particularly interesting or disturbing image. Segment 5: Patio de Abedules - the men were allowed to sit on the bench in the open air for a few minutes a day under strict supervision. Because they could not see, they depended on their sense of smell and developed a secret code of sounds to communicate. Wait, say more! But the audio goes dead. Segment 6: Cells and Torture rooms... The women's cells had a window painted over through which they could see the men being taken to the torture rooms. They could identify the men and their torturers. Next door to them was a room called the parrilla (or grill) where prisoners were stripped, bound to metal bed and tortured with electricity. End of section. No, let me down easy! Next segment... The same bland tone speaks unimaginable brutality and describes the voice of the woman captive with a voice like Edith Piaf's who sang to drown out the screams of the torture. Even when the voice cites specific testimony, there is no change in tone. The monotonous, steady rhythm (with the slight tilt at the end of each phrase), flattens out the re-telling. I take in the facts but find it hard to relate to the events and to the space. The voice does not speak to me, and I find the disconnection between the tone and tale distracting. Also it is pernicious, as if we could separate out the different moments, routines, and spaces. The pauses between segments too seem very different from Matta's recounting. His silences were full of memory. His face, body, mood, transmitted his thinking processes and affective swings. I cannot identify the silences of the audio-they were simply blank nothing, not even tape. If forgetting and silence are full of memory, full of life, the audio has a hard time capturing that life. I felt dutiful, but not engaged, as I followed the voice around Villa Grimaldi. It was a pedagogical experience; a physical exercise in Never Again.

What does this tour ask of me? The voice thanks me for my visit. It explains that Villa Grimaldi is a material and symbolic trace of State Terrorism under Augusto Pinochet Ugarte. The explanation clearly lays out the criminal practice linked to neo-liberal economic politics. It says that the visit is a look to the past. Still, "we hope" (says the unidentified voice) that it prompts reflection on the present and an impetus to halt human rights abuses throughout the world. If "I" am interested in knowing more, then please visit the web page etc. She also gives me a phone number.

It is not an exaggeration to state that future knowledge of this site will only be available through archival materials - the audio tour, the replicas, the memorial wall, the art pieces staged in the experiential practice that characterizes current memorialization practices. We enter the space that has been set up in such a way so that the archival objects might spark an affective reaction in the visitors. But it is hard for me to imagine that these objects will move someone who has not been involved in the practice, who has never been to the site, or who has no connection to what happened 
there. The punctum, or the trigger, has to come from somewhere in the viewer/listener. Trauma lives in the body, not in the archive

I take the headphones back to the office and speak to the woman who works there. Her father had been a prisoner at Villa Grimaldi who never spoke of his experience, though he has come back to the camp/park/memory site a couple of times. She worries that her office will close down - the new right wing government that succeeded Bachelet is not that interested in looking back. The newly inaugurated Museum of Memory, she tells me, also lost $40 \%$ of its operating budget. The repose offered by the domestication of Villa Grimaldi and the lulling voice is not as untroubled as it seems. These are still contested spaces and contested pasts.

When I asked the people who created the audio about choosing a young actress with no ties to the violent past to narrate the walk-through, they said they wanted the younger generations to identify. This, then, is no longer about Matta, and trauma, and justice deferred. It is about getting the next generation to understand the past.

The Parque de la Paz, I have suggested, continues to be a highly practiced place. The violently contested history of spatial practices returns and disturbs the present. On the evidentiary level, Villa Grimaldi demonstrates the centrality of site in individual and collective memory. What happens to that space is tantamount to what happens to Chileans' understanding of the dictatorship: will people repress, remember, transcend, or forget? The warring mandates about the space rehearse the more salient public options: tear it down to bury the violence; build a commemorative park so that people will know what happened; let's get beyond violence by hosting cultural events in the pavilion; forget about this desolate place, forget about this sorry past. Nowhere is there talk of justice or retribution.

Memory, we know, is linked to place - one clear reason why that place needs not only to exist but to be marked. For any guide, routine serves a mnemonic function people can remember certain events by associating them with place. ${ }^{5}$ But for a survivor of torture, going back to the site, the recorrido is a memory path - through the act of walking, the body remembers. Memory always entails reenactment, even in our mind's eye. The audio tour too is organized as a "walk." But the voice, clearly recorded in a studio free of all background noise, removes us from space. Neuroscientists suggest that these memory paths are physiological as well as material, fixed in the brain as a specifically patterned circuit of neurons. A change in Matta's routine might well change the affect. But routine also protects against unexpected affect - the audio tour is contained. It neutralizes, it encapsulates.

The questions posed by these dark sites extend far beyond the fences built around them. The small model near the entrance is to Villa Grimaldi what Villa Grimaldi is to Chile, and what Chile is to the rest of the Americas: a miniature rendition of a much larger project. There were 800 torture centers in Chile under Pinochet. If so many civic and public places like villas and gyms and department stores and schools were used for criminal violence, how do we know that the whole city did not function as a clandestine

${ }^{5}$ ABERCROMBIE. Pathways of memory and power: ethnography and history among an andean people. 
torture center? The scale of the violations is stunning. The ubiquity of the practice spills over and contaminates social life. The guided tour through Villa Grimaldi gives us the violence only appears isolated and bracketed from everything that surrounds it, accentuating the knowledge that criminal violence has spread so uncontrollably that no walls can contain it and no guide can explain it. We might control a site and put a fence around it, but the city, the country, the southern cone, the hemisphere has been networked for violence - and beyond too, of course, and not just because the U.S. openly out-sourced torture. I actually do always know what happened here/there and accept that this, like many other sites, is my responsibility. I do participate in a political project that depends on making certain populations disappear. I am constantly warned to keep vigil, to "say something" if I "see something." Though I shirked responsibility when I first met Matta - the Mexican government had nothing to do with the Chilean coup - there is anther layer. After years of my own self-blinding, I realize that the Mexican government under then President Luis Echeverria disappeared thousands of young people, about the same age as I was then. Now that I live and work in the U.S., I know my tax dollars pay for Gitmo and who knows what else. Something has been restored through the tours, with all their differences, that brings several of my worlds into direct contact. As the multi-tiered space itself invites, I recognize the layers and layers of political and corporeal practices that have created these places, the practices and politics of historical transmission, the personal histories I bring to them, and the emotions that get triggered as we walk through them in our own ways. I experience the tour as performance, and as trauma, and I know it's never for the first, or last, time.

\section{RESUMO}

O trauma é um modo de se transmitir o passado no agora, reativando-o. Este texto discute o trauma como uma experiência de natureza duradoura, como história vivenciada e como prática incorporada.

PALAVRAS - CHAVE

Performance, trauma, memória 


\section{REFERENCES}

ABERCROMBIE, Thomas A. Pathways of memory and power: ethnography and history among an andean people. Madison: University of Wisconsin Press, 1998.

GODOY-ANATIVIA, Marcial. The body as sanctuary space: towards a somatic topography of torture. Unpublished manuscript, 1997.

LAZZARA'S, Michael J. Chile in transition: the poetics and politics of memory. Gainesville: University Press of Florida, 2006.

MEADE, Teresa. Holding the junta accountable: Chile's "sitios de memoria" and the history of torture, disappearance, and death" writes that Villa Grimaldi was the "only "memorial" of torture in Latin America when it was built in 1995. Now "Parque de la Memoria" and ESMA in Buenos Aires also function as memorials. Radical History Review, v. 79, p. 123-139, 2001. Available at: < http://muse.jhu.edu/journals/ radical_history_ review/v079/79.1meade.html>. Access on: 24 Oct. 2008. 